\title{
Land Donations and the Gift of Water. On Temple Landlordism and Irrigation Agriculture in Pre-Colonial Bali
}

\author{
Brigitta Hauser-Schäublin
}

Published online: 1 March 2011

(C) The Author(s) 2011. This article is published with open access at Springerlink.com

\begin{abstract}
The Batur Temple (Pura Ulun Danu Batur) in Kintamani is located at the geographic apex of a so-called ritual water hierarchy and has conventionally been described as a purely religious institution responsible for the coordination and distribution of the irrigation water. However, an analysis of historical palm leaf manuscripts reveals that the temple had a firm economic base with corresponding interests and that it was one of the most important land-owners in late pre-colonial Bali. The article therefore explores from a socio-political and economic perspective the implications of this form of temple landlordism and its combination with ritual water control, particularly for the peasants and the portion of their annual surplus that they were obliged to deliver to this temple.
\end{abstract}

Keywords Bali $\cdot$ Water management $\cdot$ Subak $\cdot$ Wet-rice production $\cdot$ Landlordism $\cdot$ Temple

\section{Introduction}

The Batur Temple (Pura Ulun Danu Batur) in Kintamani District has played a crucial role in the ritual administration of irrigation water since pre-colonial times. I argue here that, due to its cooperation with ruling houses, the temple managed to become a major landowning institution that owned rice fields in many of its supporting villages in precolonial times. By analyzing the palm leaf manuscripts kept in the temple I show how the peasants were tied into a gift

\footnotetext{
B. Hauser-Schäublin $(\varangle)$

Institute for Cultural and Social Anthropology,

University of Göttingen,

Theaterplatz 15,

37073 Göttingen, Germany

e-mail: bhauser@sowi.uni-goettingen.de
}

and tribute relationship with the temple that controlled both land and the water flow from the Crater Lake to the fertile plains. Thus, the temple displayed some features wellknown in other parts of South and Southeast Asia as "temple landlordism".

Irrigation agriculture depends on three main factors (apart from environmental conditions and crops that need scheduled irrigation): access to suitable land, availability of sufficient water, and manpower. The first factor involves questions of proprietorship and land user rights, while the second involves not only water rights and distribution but also technical, agricultural and calendar knowledge. The third factor, the manpower needed to set up and maintain the infrastructure of irrigation agriculture, is dependent on demographic factors such as population density in relation to the land and water available. Only through the combination of all these three dimensions is irrigation agriculture likely to emerge and to be sustained conditional on enabling social and political circumstances. Each of these three factors will be independently analyzed within the encompassing socio-political and economic system in terms of actors competing for these resources. Typically in complex societies this includes groups beyond the actual cultivators, such as gentry, priests, traders, craftsmen and other specialists. Following Eric Wolf (1966) I shall call such cultivators "peasants" and not "farmers". 1

The relationship in Bali of these three productive inputs, land, water, and manpower, is unique to Bali. There, irrigation water is symbolically paralleled by sanctified or

\footnotetext{
1 'Farmer' suggests production based on agricultural entrepreneurs with a primarily business orientation, a business enterprise, "combining factors of production purchased in a market to obtain a profit by selling advantageously in a products market. The peasant, however, does not operate an enterprise in the economic sense; he runs a household, not a business concern" (Wolf 1966, p.2).
} 
"holy water" termed tirtha (see Lansing 1991, p.55-59). Tirtha is prepared and distributed by priests at all ceremonies to men and women regardless of their social standing or their way of life. It is considered the elixir par excellence that is needed for the prosperity of the fields and the crops and for livestock as well as human beings. Various kinds of tirtha exist, but all share a strongly integrating function: through tirtha, land, irrigation water, and human beings are symbolically united in a ritual order. To put it differently, tirtha creates its own specific chain of dependency or hierarchy. As we shall see, the notion of holy water as an ultimate means of purification and blessing is crucial for the understanding of the ritual control of the irrigation water- and of the land.

This paper deals with the late pre-colonial era with emphasis on the $19^{\text {th }}$ century. Since some sources are earlier and - for comparative reasons - some issues need to be illustrated by recent examples, the time frame will not be entirely consistent as will be pointed out.

\section{Land and Land Ownership}

Landownership in Bali was (and still is) highly multifaceted. Land rights has been treated in almost all the literature as a 'secular' matter. However, this is a very limited perspective. According to detailed studies Bundschu (1985), even in pre - and early colonial time there were regionally differentiated co-existing systems:

1) Land within village boundaries was of two types a) communally owned land used (for example in a rotation system) by the members of the village, b) land (mostly virgin land) which could be claimed by individual villagers for their own use with an annual payment to be made or services rendered to the village. As soon as these fields were no longer worked, they reverted to being communal property.

2) Land owned by noble families (predominantly rulers) that was given as fief to tenants on a share cropping or tribute/tax basis. In this system, cultivators were additionally liable to provide services to the noble landowners (in the patrimonial or feudal domain). ${ }^{2}$

3) Royal land that had to be worked by villagers and members of irrigation associations (subaks) in corvee labor. Royal land came into being through different strategies: a) through warfare; such land was called paoman, and could be given to a village for communal,

\footnotetext{
${ }^{2}$ Bundschu presented evidence from early colonial sources that - in contrast to H. Geertz's (1963) claim - there definitely also existed a 'feudal system of landlords' with regard to agriculture (Bundschu 1985, p.33). Such land was called pecatu in Bali.
}

but not individual use. The village as corporate body had to fulfill services for the king in return; b) by law in the case of childless couples, widows or wrongdoers (camput right); or c) if virgin land had been turned by peasants into agricultural land and irrigated at the request of the king.

4) Land (owned by villages or a ruling elite) granted to office holders and tied to their period of office; grantees were allowed to use the yield for their own benefit (the prebendal domain). This land was mostly tax free.

5) Land that was owned by individuals without any obligation towards any higher authority. This land could be left to descendants. However, land never seems to have become a commodity that could be freely sold from one individual to another. ${ }^{3}$ All land was apparently seen as being enclosed within specific village territories. All proprietors, whether members of a communal owner group or individuals, were obliged to render services (ngayah desa) towards the village to whose territory the plot or field actually belonged (Bundschu 1985, p.28-36). ${ }^{4}$

Bundschu regards these different forms of land ownership as regional peculiarities rather than as systematically interrelated. Nevertheless, these different forms cannot be as neatly separated from each other as Bundschu seems to suggest (Bundschu 1985, fig. 10). In fact, within any village territory the agricultural land could be allocated among differing co-existing systems of landownership (see also Pedersen 2006, p.167). Changing political conditions created a dynamic land rights over time. The Balinese state episodically alternated between periods of centralization and decentralization the late pre-colonial and early colonial era (see Hauser-Schäublin 2004). Access and control over land oscillated between hierarchically organized and communally structured systems of land ownership - with all the variations and combinations mentioned above. Thus, during periods when nobles became rulers a new domain, their courts established (or re-established) systems that turned peasants into tenants. ${ }^{5}$ In times when a ruling dynasty gradually lost its power, villages asserted their own control over land through such socio-political organizations as

\footnotetext{
${ }^{3}$ In the area of Sembiran and Julah on the north coast, individual land owners could, in a sense, ,sell' their land to members of other villages. However, this 'selling' was rather a leasing than a selling since the new tenants were not allowed to sell this land to other villagers but only to members of the village from which they had originally acquired the land (Liefrinck 1924, p. 383). In this way, land seems to have been inalienable.

${ }^{4}$ These services consisted mainly of obligations towards the village gods and their temples (participation in rituals, consecrating offerings, etc.).

${ }^{5}$ Sembiran village, located on the north coast, is a good example for the study of such shifting processes during the early colonial period; see Hauser-Schäublin 2008a.
} 
based on principles of seniority and membership in ritual moieties involving married couples (krama desa).

\section{Water and Control over Water}

The broad range of possibilities whereby land use, land ownership and manpower were combined in changing political circumstances presents a challenge to the organizing of a stable and continuous supply of water This paper views the subak local/regional watershed organization of integrated water resource management, as a distinctive Balinese institution as a response to these circumstances. In this system the flow of irrigation water does not follow principles of social hierarchy or distinction according to class, rank or political power. The subak is an association or corporate body based on the water system itself: "all individuals owning land [or rather peasants who are actually cultivating the land] which is irrigated from a single water source- a single dam and canal running from dam to fields - belong to a single subak" (Geertz 1959, p. 995; see also Lansing 1991, 2006; Schoenfelder 2003; Jha 2002). Each subak has an elected head, the pekaseh, who organizes all duties and obligations. The members of a subak have a common goal, which is to ensure the food supply and the maximization of the harvest yield by guaranteeing a stable flow of water. It does not matter if the cultivators work under different property and land use conditions in the paddies. The subak organization avoids the danger that a rich and noble landowner may appropriate a greater share of water than his subjects, poorer peasants and landless tenants. The subak therefore appears at both local and regional level to be a pragmatic organization of cultivators in the form of a working partnership.

Many sources have, however, made it clear that under a powerful king or dynasty the subaks were exploited in many ways (see also Petersen 2006, p.306). The king sometimes created new subaks when he wished to have new land opened up and turned into irrigated rice fields called sawah. In addition to the material that Bundschu extracted from colonial sources an indigenous document, Pambencangah Dane Poleng, gives evidence of an $18^{\text {th }}$ century Balinese ruler over Lombok who directed the peasants to form subaks in order to have land developed into irrigated rice fields (Hägerdahl 2001, p.122-123, 125-126). In spite of this mixed heritage subaks survived in different political systems up to the present

Water in Bali was never regarded as an "open access" resource which allowed unregulated use for agricultural purpose (Strauß 2006, p.33). Water was (and still is) considered to be a gift of the gods. Thus water was first and foremost 'owned' by the gods and only in the second instance controlled by those who were blessed by them and acted on their behalf, namely priests of "water temples" that were, according to Lansing (1991) responsible for the coordination and ritual regulation of the flow of irrigation water, and also kings and their local representative nobles. Even kings were not seen as owners of the land in their own right, but on behalf of the gods. A king was believed to be in power only if the gods looked on him favorably. The relationship between gods and king was delicate and needed to be cultivated especially through ties to temples and priests (see Hauser-Schäublin 2003, 2004, 2005; Hauser-Schäublin 2008b). Even rulers depended on cooperation with the priests of the "water temples" for water for the growing of rice.

A ruler could use water for political ends. It often happened that a channel crossed the territories of a number of different sovereigns. Where conflicts occurred between neighboring sovereigns water was often used as a weapon (Hauser-Schäublin 2003:161) The ruler of an upriver regency was able to use the water in two different ways either by diverting the flow of water so that the plants in the peasants' fields of his lowland enemy withered, or by damming up the water and then breaking the dam so as to cause a flood further down-river. In this sense control over water has to be seen in a hierarchical context as a sovereign could, if he wished, over-rule a subak's control over water. Apart from the use of water as a weapon, the control of water gave (and still gives) rise to many quarrels, most often between up-river and down-river subaks. Especially in regions where water was not plentiful (for example in North Bali) the down-river subaks often did not receive enough water to irrigate their fields because upstream cultivators had depleted it. In such cases the subaks often actively requested the interference of the king and/or the official appointed by him (the sedahan agung). It was the king who then set up a written regulation (sima subak, see Liefrinck 1921) and a schedule as to which subak was allowed to make use of the water, when and for what purpose.

\section{Historical Background of a "Water Temple" and its Organization}

The Batur Temple (today called Pura Ulun Danu Batur) in the district of Kintamani is situated on the caldera of a primeval volcano (see Wälti 1997; Lansing 1991, 2006; Reuter 2002). Before the Batur volcano erupted with heavy lava floods in the first decades of the 20th century, Batur village and its temple were located at the foot of the volcano. This temple is today one of the major 
institutions in charge of the ritual control of the flow of water. $^{6}$

The temple organization joined political and religious power in a number of ways in the 18th and 19th centuries. As an institution the temple was then one of the most important land owning and tribute-collecting bodies in Bali. In this regard, it displayed similarities with South-Indian temples (see for example Appadurai 1981; Rudner 1994; Stein 1980, 1989; Dirks 1987). Ethnohistorical research carried out in the Batur area between 1999 und 2009 and on (only partly dated) palm leaf (lontar) manuscripts, known collectively as the Rajapurana Batur, that are kept in the Batur Temple and have been transcribed by Budiastra $(1975,1979)^{7}$ outlines the path of historical development of the institution.

By reference to certain events they describe, the lontar manuscripts appear to cover a period between the 17th and the late 19th centuries. ${ }^{8}$ What seems to be clearaccording to different sources, among them the lontar text "Pratekaning Usana Siwasasana" (Budiastra 1979) — is that the Batur Temple is the result of the colonizing efforts of immigrant Javanese nobles from Majapahit between the 16 th and the $17^{\text {th }}$ centuries. ${ }^{9}$ Before, there apparently existed a number of more or less independent settlements which formed alliances and networks of cooperation with ritual and political goals. The struggles of such an alliance against outsiders and the immigrants' efforts to control the mountain settlements finally ended in an agreement. The (surviving) inhabitants were 'persuaded' to give up their individual villages and to settle all in one (to be newly

\footnotetext{
${ }^{6}$ As indigenous texts from the $19^{\text {th }}$ century make clear, there were several other "water temples" located near other lakes (for example the lakes of Beratan, Buyan and Tamblingan, Batukau) in the mountains of Bali (van Eck 1878, p.110); they had a similar function in relation to their watersheds as the Batur temple has to its own.

${ }^{7}$ The palm leaf manuscripts are, with few exceptions, undated. Palm leaves deteriorate over time and need to be copied at regular intervals. But at the same time, this material allows easy replacement and change in case the contents, especially of political nature, were no longer in agreement with the actual political situation.

There exist even earlier Batur inscriptions (copperplate inscriptions) which display similarities as well as differences with the lontar manuscripts; the copperplate inscriptions will not be considered here (but see Hauser-Schäublin and Ardika 2008).

${ }^{8}$ Some of the dates and names of ruling sovereigns seem to have been erased over the years; this evidently happened when political power relations drastically changed. Therefore the period in which the events described took place can be estimated only.

${ }^{9}$ However, the mountain region had already evidently been tied up before in complex relationships with ruling houses, the earliest court of which still traces exist was probably located in the mountains and not in the south of the island. The most important ruling house was once situated on the site where a temple stands today, Dalem Balingkang (see also Reuter 2002, p.130-142). For a more detailed discussion about the coming into being of the Batur temple and its relation to the Dalem Balingkang temple see Hauser-Schäublin 2003:167-168)
}

established) place, Batur. ${ }^{10}$ From the beginning, marriage alliances with local clans safeguarded peaceful relations between the local population and the noble houses. King Waturenggong is considered to have been responsible for the temple's coming into being. Henceforth it seems to have served as a sanctuary where sovereigns received their blessings from the gods; they established an ancestral shrine beside the shrine of the most important local deity. The new temple combined symbolic and practical economic tasks, namely the promotion of the fertility of the world and the safeguarding of the flow of water. These duties had been shared by two preceding sanctuaries, one bearing the name of Sinarata, the other of Tampurhyang. Waturenggong (and succeeding sovereigns) is said to have sent an official representative to Batur. The office of Mekel Agung, the royal functionary in charge of an administrative unit, goes back to the post-Majapahit time. ${ }^{11}$ The Rajapurana Batur texts suggest that representatives of 45 villages (desa setimahan) - members of a former alliance or networks of villages - were also based in Batur village. Even today, the Batur Temple is a place in which gods or deified ancestors from different descent groups and different locations (villages) are assembled, including some noble houses as well.

According to the Rajapurana Batur, the leading deities before the Batur Temple was built were I Ratu Sakti (Susunan) of Sinarata and Ratu Sakti Bujangga Luwih of Tampurhyang; the latter was associated with the Batur Lake. Today, the leading deities in the Batur Temple are Dewi Danu (The Goddess of the Lake) and Ratu Meduwe Gumi (The Ruler Who Owns the World, also called Waturenggong, Toh Langkir and Putrajaya). ${ }^{12}$ Dewi Danu is today the deity of the Crater Lake, the goddess who controls the water that flows subterraneously from the lake and fertilizes large parts of Bali (see Lansing 1991, p.73-77). Ratu Meduwe Gumi is associated with the Batur Volcano. Together, they represent a powerful couple that ritually controls the fertility of the island. What is important in this context is that the temple has always been affected by the social and political conditions of the time and has changed accordingly. The same applies to the social organization of the temple, the offices and to the office-

\footnotetext{
${ }^{10}$ Wiener gives Kresna Kapakisan, a "Brahmana Buda" who came to Bali in the $14^{\text {th }}$ century as the man who had to face the rebellious mountain villages in the Batur area (1995, p.107; 110-113, n.18).

${ }^{11}$ The office of the mekel replaced the office of a bendesa, which, according to the Rajapurana Batur, was once the name of a group that passed down the office by inheritance.

${ }^{12}$ The last two names symbolize the highest volcano in Bali, Gunung Agung. All these names have to be understood as "The One Who Rules the World"; Waturenggong, the famous $16^{\text {th }}$ century ruler, is considered to be the worldly representation of the other supreme male gods that I mentioned above. Dewi Danu and Ratu Meduwe Gumi are usually regarded as siblings.
} 
holders' duties. With the abolition of kings and kingship by the Dutch Colonial Power in the late 19th and early 20th centuries and, later, with Independence, the structure of the temple and its organization partially changed again, with several characteristics surviving in altered form.

\section{The Social Organization of the Batur Temple and its Predecessors}

Today there are six categories of temple officials of different social origin and each with special obligations and rights. There are two high priests, called Jero Gede ${ }^{13}$ in the service of the major gods (Dewi Danu and Ratu Meduwe Gumi). They are independent of the Batur village organization. The same applies to the two Jero Penyarikan, the two Scribes or Registrars, who perform their duties for the Jero Gede. Both the Jero Gede and the Jero Penyarikan have roots in royal houses. ${ }^{14}$ The two Jero Gede are considered to be the 'owners' (on behalf of the deities) of the temple. Further, there are two female virgin priests, Jero Balian, of autochthonous, that is, local descent. They have special duties related to rituals that are supposed annually to revitalize the fertility and the prosperity of the world. ${ }^{15} \mathrm{~A}$ total of about 22 priests (mangku) are each in charge of a particular god there. All these temple officials together are called kedangka. In addition, there is the ritual village organization of Batur village, a dual organization with hierarchically ranked offices based on seniority, the balirama. The balirama formally consists of $16^{16}$ male members. ${ }^{17}$

\footnotetext{
${ }^{13}$ In the Rajapurana texts they are mostly called mangku Bukit/ Bukutan; today this is taken to be a higher rank which a Jero Gede reaches only after a further consecration ritual (abhiseka).

${ }^{14}$ Today, since democratization has become an important movement in Bali as well as in other provinces of Indonesia and most of the ethnographic literature on Batur has emphasized the egalitarian organization of the Batur Temple, most officials publicly emphasize their local roots while privately communicating that those go back to noble houses, a stance that is not politically correct in today's climate. ${ }^{15}$ In the Rajapurana texts the Jero Balian (called Balian Desa) are mentioned as being responsible for the whole ritual of the tenth Balinese month, the major fertility ritual. Today they have become replaced to a considerable extent by the Jero Gede.

${ }^{16}$ According to the Rajapurana Batur texts, and according to informants, there used to be four leading offices, two kubayan and two baw. These offices have now become obsolete. The individual Rajapurana texts differ with regard to the numbers (and names) of the individual offices. Today, due to an increase of Batur's population there exist three administrative units of Batur village, each having a balirama.

${ }^{17}$ Their wives are not counted though they have important functions. They are mainly responsible for the manufacture of the innumerable offerings, each of which has a special purpose and occasion when used.
}

The sixth category consists of a single office called Jero Petinggi; he is associated with the deity I Ratu Ayu Karang Buncing (The Deity of the Twins of Opposite Sex). ${ }^{18}$ Jero Petinggi - the name is limited to the ritual sphere- holds a double office: he is the highest leader in everyday life, the perbekel, ${ }^{19}$ and also has an outstanding honorary position in the temple as Jero Petinggi. During the festival Jero Petinggi has an organizing and directing function especially when guests of high standing arrive. During the large procession during the annual festival of the $10^{\text {th }}$ Balinese month, when dozens of villages join the huge procession in front of the temple, he is responsible, together with the Jero Gede, for the correct order of procession. And it is he who nowadays at the end of the temple festival announces the amount of money that has been donated to the temple during the ritual and how much money has been spent (see below).

These 45 members of the Batur board together are called gep or desa setimahan ('Village of the 45', see above). Gep meets at regular intervals in front of the Bale Pesamuan, a shrine in the adjacent village temple; gep symbolizes the unity of the temple board.

Batur village and Batur Temple were related, among others, to another sanctuary - nowadays called Jati Temple - that existed nearby. The Jati Temple is a Bujangga Temple. Bujangga is today taken to be the name of a distinct descent group and at the same time what Goris called "a sect" (see Goris 1986) though today their rituals do not show any difference to those performed in nonBujangga temples.

In some of the Rajapurana Batur texts the Bujangga is called "Bujangga Buda" or "Bujangga Boda" suggesting that this denomination was related to Buddhism rather than Siwaism. The deity "I Ratu Sakti Bujangga Luwih" mentioned in the Rajapurana Batur is today still the major deity in Pura Jati. According to oral traditions the 'predecessor' of the Jati Temple ${ }^{20}$ — definitely located at a different site from today's temple, and most likely a Buddhist monastery ${ }^{21}$ — apparently one that was the center of a network of sanctuaries located in different parts of Bali. Once a year, at the festival of the New Year, representatives of all these branches of the 'clan' (Kayu Slem) responsible for

\footnotetext{
$\overline{18}$ Twins of opposite sex are assumed to have had sexual intercourse in the mother's womb during pregnancy. The birth of such twins still throws some villages into a state of impurity since the couple in the mother's womb is associated with incest, one of the worst offences.

${ }^{19}$ Today, the perbekel is elected by the villagers. However, the office holder of the village section I studied in detail still is in an unbroken line with his predecessors and linked to the nobility of Bangli. The word perbekel is a linguistic variation of mekel.

${ }^{20}$ Whether Pura Jati's 'predecessor' was the site called Tampurhyang in the Rajapurana texts has so far not been established.

${ }^{21}$ The sacred heirlooms of Pura Jati still kept in the Batur Temple support the thesis that it was a former Buddhist place since these heirlooms consist of high priest regalia.
} 
many rituals related to this temple and accompanied by novices (boys) from villages, some of them quite far-off, gathered there. ${ }^{22}$ Still today, during the festival an initiation of boys and girls (aged between 10 and 19) into the office of priests takes places. They undergo purification rituals, their head is shaved and they are clad in white garments. They are hence considered escorts of the deities of this temple.

The reason why this monastery and today's Pura Jati having been so important is the fact that the priests there were in charge of the (Indian) saka calendar. They were responsible for the annual establishment of the date of the beginning of the New Year. The date for each New Year depended on the reappearance of the Pleiades in July/ August (sasih Kasa). This set the calendar for the agricultural cycle and its regional coordination, and more specifically for the timing of the movement of the irrigation water from the source through the valleys to the sea. The calendar also laid down a binding schedule for all the occasions (temple festivals) when the villages were expected to come to the temple.

Today, the calendar no longer needs to be calculated each year since it appears annually in printed form. In the old days, however, the determination of the annual cycle by means of a binding calendar was essential. The New Yearon the full moon day of the $1^{\text {st }}$ Balinese month - is still celebrated at Pura Jati. The final festival that celebrates the end of the agricultural and annual cycle was, and still is, the big ritual of the $10^{\text {th }}$ Balinese month that is held at the Batur Temple. ${ }^{23}$ In the pre-Batur Temple era both 'temples' and their major deities, I Ratu Sakti (or I Ratu Susunan Sakti) of Sinarata and I Ratu Bujangga Sakti of Tampurhyang, used to cooperate in the ritual control of the water and the prosperity of the whole world, subject to the framework of the calendar. There are indications that the Buddhist sanctuary with its monks or priests (I Ratu Sakti Bujangga ring Tampurhyang) was in charge of the calendar and, therefore the flow of water, while another sanctuary and its priests (I Ratu Sakti ring Sinarata) was responsible for the fertility of the soil and of land in general. Both institutions however, after the successful 'unification efforts' by the Majapahit immigrants when they tried to establish their rule throughout Bali, did not merge into a single institution with equal integration of two different principles of organizations or denominations. ${ }^{24}$ Instead, the Jati Temple finally

\footnotetext{
${ }^{22}$ I have evidence for this for Sembiran village on the north coast; young boys designated as mangku putih officiated as escorts of the Batur deities (see Hauser-Schäublin 2008a).

${ }^{23}$ Today, the celebration of the New Year is generally held throughout Bali in March/April at the spring equinox.

${ }^{24}$ Such as Siwaite and Buddhist priests; integration has occurred in a similar situation, in Sri Lanka for example, where a "vihara system", Buddhistic monastery, and a "devale system", Hindu deities, were incorporated into a single temple; see Evers 1972.
}

'surrendered' ${ }^{25}$ to the Batur Temple; it no longer has an organization of its own. Today, Pura Jati is more or less incorporated into the Batur temple and Batur village is responsible for the maintenance of both temples.

\section{Donations of Land, Landed Temple Property, and Land Rents}

However, from an economic perspective, it is important to note that the Batur Temple has always been an affluent institution: the temple owned an impressive amount of landed property. It was able to accumulate wealth while at the same time functioning as a redistribution centre (Hauser-Schäublin 2005, 2008b). The Batur Temple has a geographically wide-spread net of supporting villages ${ }^{26}$ whose residents still regularly make a pilgrimage (either by sending deputies or by going there collectively) to the Batur Temple, mainly on the occasion of the annual festival of the $10^{\text {th }}$ Balinese month. These villages are called pasyan. ${ }^{27}$

Although most literature on irrigation agriculture and its social organization have concentrated on subaks and pointed out their supra village character, it is worth noting that the pasyan recorded in the old registration list of the Batur Temple are villages and not subak irrigation associations. ${ }^{28}$ Nevertheless, the Batur Temple succeeded in having both villages and subaks tied to the temple. This is not surprising since villages and subaks are not discrete units. Both are made up of peasants who are simultaneously members of a particular subak and a particular village community.

With regard to land, many of the pasyan villages were bound to the Batur Temple by a system of property rights

\footnotetext{
$\overline{25}$ The Buddhist priests were superseded by Siwa (Brahmana) priests. Oral traditions indicate that the sanctuary was taken over by Brahmana priests after the arrival of the legendary Brahmana priest Dang Hyang Nirarta from Java. The former office holders surrendered their power to the newcomers. Unfortunately, there exists (to my knowledge) no lontar or copper plate inscription that contains any record of the history of the Jati Temple.

${ }^{26}$ As a matter of course, all Bali-wide important temples have widespread nets of supporting villages, the best researched so far are Pura Penulisan (Reuter 2002) and Pura Besakih (Stuart-Fox 2002). Pura Penulisan, Pura Dalem Balingkang und Pura Batur are interrelated.

${ }^{27}$ The linguist Dr. I Nyoman Suarka, Universitas Udayana Denpasar/ Bali, suggests that pasyan has its roots in sisya, the disciples of a spiritual leader (pers. communication). This interpretation is supported by evidence from the state temple of Batu Karu in West Bali. There, the villages dependent on the holy water from this mountain temple are called "sisia Batukau" (Ottino 2000, p.20)

${ }^{28}$ It is only recently that the names of subak have started to be regularly used, as the registration list of the Batur Temple established at the festival of the $10^{\text {th }}$ Balinese month in 2007 documents. As I will show below, this change is probably due to the fact that the Batur Temple is officially (according to the land register) no longer a landowning institution.
} 
since the Batur temple owned irrigated rice fields there. The question arises as to how the temple acquired such land. The registration list of the pasyan villages shows that, apart from the core (or oldest) pasyan, the names of new villages appeared pari passu with the shifting power relations of local and regional lords to a superior sovereign and his ties to the temple (Hauser-Schäublin 2008b). In the few cases where we have data, gifts of land to the temple were mostly initiated by superior sovereigns following negotiation with local or regional lords. One case from the early 1880 s clearly illustrates how the king of Bangli bestowed a noble title (gusti) on a local leader (of common origin) of Apuan village who had freed himself and his village from an autocratic ruler and was seeking an alliance with the kingdom of Bangli. This title granted him higher social standing in the village as well as recognition and access to the royal court (see Hauser-Schäublin 2004, p. 335). In exchange, the king asked the local leader to donate rice fields to the Batur Temple. This village land was then entered in the temple register. In turn, since the gift of land went back to the royal initiative, the king asked the temple for privileges as well, such as the establishment of an ancestral shrine in the temple precincts. ${ }^{29}$ The name of the deity Ratu Meduwe Gumi (The One who Rules the World) was also a metaphor for the superior king (at that time: Bangli regency) who was patron of the shrine for I Ratu Meduwe Gumi. ${ }^{30}$ This example illustrates the complexity of the relations among villages, lords, temples, and land.

For the villages this had far-reaching economic consequences. By agreeing to donate land - rice fields - to the temple, the village became obliged every year to bring a substantial part of the harvest yield to the temple, and a patrimonial relationship came into being. Thus, the peasants who had to till this land- probably the village as a corporate body - became share croppers of the temple, which was now a land proprietor.

This method of donating land to the temple used to be a common practice. It is likely that only few villages themselves offered land to the temple on their own accord. This interpretation is supported by the fact that after the abolishment of kings and kingship by the Dutch and, subsequently, after Independence, the awareness in the villages that the Batur Temple once owned substantial parts of their best land gradually faded. This processes were certainly accelerated by the land reforms the Dutch and later, after Independence, Indonesia, administered. Thus, this land was never entered in the official land register of

\footnotetext{
${ }^{29}$ The small temple owned by the former gusti-family of Apuan which is located in the north-eastern corner of the Batur temple is a testimony of this negotiation in the $19^{\text {th }}$ century.

${ }^{30}$ Today, it is the Head of Bangli Regency (to which Batur belongs) who is associated with this shrine and its deity (see Hauser-Schäublin 2011).
}

the Province of Bali. ${ }^{31}$ Nevertheless the villagers have kept up their annual deliveries (harvest yields) to the temple. They see this form of tribute today mainly as payment in kind for the irrigation water and the holy water (tirtha) the symbolic essence of fertility - that they receive. The peasants nowadays explain their involvement with the Batur Temple in terms of water alone although they were formerly tied to the temple in two ways. These villagesand this explains the long lists of names of villages (and not subak) spread over several regencies and registered in the Batur Temple - were primarily bound by ties of land ownership rights and obligations to the temple.

Three of the major Batur manuscripts (Babad Patisora, Pengacin-acin Ida Bhatara and Pratekaning Usana Siwasasana, see Budiastra 1979) document the fact that the Batur temple (as well as its predecessors) used to be one of the biggest institutions with landed property in Bali so far known: Babad Patisora and Pratekaning Usana Siwasasana contain the names of 76 pasyan villages, Pangacin-acin Ida Bhatara lists $62 .{ }^{32}$ All these manuscripts include registers that document how large the most fertile land of the territory — all paddy — was that was owned by the Batur gods (I Ratu Sakti). This property is, as one of my interview partners emphasized, not classified as laba pura, as temple land, whose usufruct is usually destined for the maintenance of the temple and the performance of rituals but as druwe; druwe is a term mainly used for landed property owned by a ruling house. The extent of the land is phrased in units of tenah. Schulte Nordholt estimates that a tenah of the old kind (it was given a definite equivalent under the Dutch colonial rule) may have varied between 2,700 and 7.500 sq.m. per tenah. The tenah was not a standard square measure but "expressed a certain amount of harvested padi (a bundle of sheaves weighing about 25 kilograms)" (Schulte Nordholt 1996, p.252; n.91.). The number of tenah the Batur Temple claimed to own in individual villages varied, according to Pengacin-acin Ida Bhatara, between one and 45. The total amount of all tenah in this manuscript comes to almost 450 tenah. If we follow Schulte Nordholt's calculation $(1$ tenah $=$ approx. $25 \mathrm{~kg})$ this adds up to $11,250 \mathrm{~kg}$ of paddy sheaves. ${ }^{33}$

While the Batur Temple on behalf of the gods acted as proprietor, the inhabitants of the pasyan villagers were obliged to keep up the fields and the irrigations system, to till the fields, harvest the paddy, bind it into sheaves and

\footnotetext{
${ }^{31}$ The Batur Temple has recently been attempting to regain official recognition of some of its landed property.

${ }^{32}$ The registration list of 2004 displays 171 entries; the one of 2007 contained over 200 .

${ }^{33}$ For a detailed account of the land property of the Batur temple and the gifts brought to the temple according to the palm leaf manuscripts see Hauser-Schäublin 2005:752-754, and http://www.uni-goettingen. de/de/29496.html.
} 
process the yield until only the grains remained. In short: the peasants were - in a sense- share croppers on the temple's landed property. It is thus a particular example of what Wolf called "patrimonial domain" (1966, p.50), or what Max Weber called "Klostergrundherrschaft", a term translated into English as "monastic landlordism". 34

In the case of Bali it would make more sense to call it "temple landlordism". The villages had to pay a land rent, primarily in kind. In the texts it is not only the amount of tenah that is registered, but also the amount of unhulled rice (in ceeng, a coconut shell measure for grains) that the village had to bring to Batur at the festival of the $10^{\text {th }}$ Balinese month. We can only estimate the weight of grain that a sheaf of about $25 \mathrm{~kg}$ contained - perhaps half. A sheaf of paddy may produce about 10 to $12 \mathrm{~kg}$ of unhulled rice if this estimate is correct. According to the manuscripts mentioned, the villages were asked to deliver about 5 ceeng or $\mathrm{kg}$ (a ceeng comes almost to $1 \mathrm{~kg}$ ) of unhulled rice per tenah to the temple. Thus we can assume that the yield of the rice fields was shared between the temple and the village on a 50/50 basis (usually called nandu in Bali, see Bundschu 1985, p.142). It now becomes obvious why the most important temple festival of the Batur Temple was scheduled after the harvest.

The lists in the Batur manuscripts have to be critically evaluated in the sense that they are lists of requests and not registrations of what the pilgrims actually delivered. However, a list of goods brought to the temple that may have been established in the first half of the 20th century illustrates that there is an astonishing congruence between the request list and the actual delivery list (see HauserSchäublin 2008b). My own investigations in 2008 and 2009 brought forward also a surprising correspondence between the goods requested and those delivered. One of the main reasons for this is that the peasants fear the curse of the gods and the refusal of the priests to provide them with holy water if they do not fulfill their obligations for three successive years. ${ }^{35}$ This, they fear, will mean crop failure, and bring other misfortunes as well.

\section{The Ritual Exchange of Blessings and Goods}

An earlier article (Hauser-Schäublin 2008b) shows that the individual villages listed in the temple register have

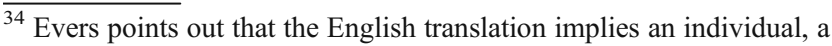
landlord, who owns land and commands tenants while the German term does not imply such a single actor. He therefore prefers the term "monastic capitalism" in his analysis of Buddhist monasteries in Sri Lanka that also "owned a fair proportion of all irrigated ricelands" (1972, p.16)

${ }^{35}$ More recently, in one of the letters addressed to the villages to bring the goods requested to the temple, the leading priests reiterated one of the old curses as documented in the palm leaf manuscripts in order to achieve compliance.
}

changed little over time. All the 'old' pasyan seem to have made the pilgrimage - during which first and foremost the share croppers of the temple land transported the land rent in kind to the temple - for centuries. ${ }^{36}$ But this land rentthe yield from the paddies, - understood as a gift to the gods in order to secure the further fertility of the fieldswas only part of what the peasants had to provide to the temple. The Batur manuscripts under discussion show a particular feature in that they do not generally ask the cultivators by name for a 'reimbursement' for the provision of irrigation water. Instead the manuscripts request such reimbursement from offices or rather office-holders: the pekasehs, the heads of subaks. They were requested to bring a certain amount of money (and to a lesser extent part of their harvest yield) to the Batur Temple. The pekaseh's office is invested with obligations and responsibilities. This is why the temple preferred to appeal to this official, and only rarely to the subak, since membership in a particular subak may shift. Apart from the pekasehs the manuscripts give the names of the villages that were requested to pay duties per dam. Sometimes the amount of money was defined according to the number of weirs or dams a subak incorporated, that is, how large the area was. The construction of a new dam was also liable to a tax (pajeg, sometimes called upeti or suwinih) in money (jinah) that had to be submitted at the festival of the $10^{\text {th }}$ Balinese month at the Batur Temple.

An encompassing and intricate web of interdependence linked gods, temple, peasants and villages. The peasant (whether as members of a subak or as a member of a village) is obliged to bring a wide range of produce to the temple as well as to provide labor. The fact that they receive the blessing of the gods for their activities in the form of tirtha in return for their gifts is a major motivation for these annual deliveries. The interaction with the gods through holy water allows them to perceive their relationship with priests, and in the old days also with rulers, in mainly noneconomic terms.

The long lists in the Batur manuscripts show different kinds of services and 'gifts' - or rather tributes - that the villages had to deliver. All these services and the delivery of goods were called "ngayah Ida Bhatara". These services and gifts can be classified into several categories. Labor obligations include the building of shrines and the construction of collections of offerings and the like in the Batur temple, performing specific tasks such as collecting gifts of money during a ceremony, beating the signal gong, escorting the deities, or performing parts of rituals under the supervision of the Batur Temple board. Among the goods mentioned are, apart from unhulled rice: the produce of

\footnotetext{
$\overline{36}$ Today there are many more villages that voluntarily bring gifts to the Batur Temple.
} 
arboriculture such as coconuts, betel nuts (pinang with betel pepper, sirih); all sorts of living animals (livestock as well as game); products of dry land (tegal) agriculture such as different sorts of beans and peas, onions, and cotton; semifinished or finished handicraft products such as leaves (for the manufacture of ephemeral offerings), cotton thread, cloth, plaited sitting mats, plaited and sewed ceremonial hangings; kitchen ingredients and produce such as mixed spices, palm sugar, cookies and fried ingredients; and the produce of inter-maritime trade such as Indian patola textiles. Apart from all these goods the temple has traditionally requested money (formerly Chinese coins, today mostly Rupiah) for the services they have performed on behalf of the peasants for the gods, money being defined as tax (upeti) for irrigation water. ${ }^{37}$

\section{Conclusion}

To summarize, property rights over land and water and the ultimate allocation of these resources are two distinct issues. The temple's landed property (druwe) - exemplified by the Batur Temple - has been so far overlooked in Balinese studies dealing with land use. Temple landlordism of this kind had far-reaching consequences for the peasants in late pre-colonial times. Fertile land is a primary resource, the ownership of which has implications for the mode of production and the deployment of labor. Water is largely important only in combination with land.

In the case of the Batur Temple, the influence of this major centre was based first and foremost on its large estates and on the ritual control of water. Both were of equal importance. They were woven into a fabric of spirituality and rituals that makes it hard to discern the actual economic and political interests of both kings and temples as institutions, as well as their interdependence. The ritualized system of resource control was the gift of water by the gods symbolized by the holy water (tirtha) prepared by the priests. This divine blessing in the form of water constituted a further resource equal in significance to the more 'material' ones. This spiritual resource was (and still is today) widely perceived as a precondition for a prosperous life. Its sustainability required reciprocity from those who were in need of it. These were first and foremost the cultivators whose mode of life depended on spiritual resources as well as more mundane ones. On the other hand, peasants were tied to a double network of obligations to the spiritual and worldly owners of these resources. It was not, however, the peasant as an individual who was the direct partner within this net of duties. Different corporate

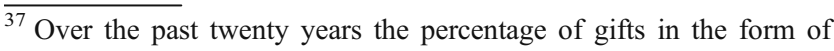
money has greatly increased.
}

bodies were partnered; the village with regard to land within its territory and the subak with regard to irrigation water.

The peasants' reciprocation involved - apart from worshipping the gods and venerating those who acted on their behalf - the transfer of a substantial part of their surplus produce to those on whom they were dependent. This transfer of services and gifts combined with the fulfillment of ritual obligations reflects the roles the peasants played in a complex irrigation based agrarian society. The transfer of goods to superior groups can be called - following the terminology of Eric Wolf- a 'rent fund' (1966:6-10 and consisted primarily of annual harvest yields. The tax the pekaseh had to pay on behalf of the peasants are what Wolf calls a 'replacement fund' in that the peasants had to invest as well to safeguard the agricultural cycle. The taxes are used, in part, for the construction and maintenance of dams and weirs. The calculation of the saka calendar was important to determine the beginning and later course of the agricultural year and for the synchronization of the waterways descending from the source in Crater Lake. This 'service' was annually rendered by the priest or monks, a service from which the peasants also benefited.

A further portion of the surplus the peasants used directly (on the making of offerings) or indirectly (by transferring it to the Batur Temple as well) can be attributed to the 'ceremonial fund' that Wolf saw as a further characteristic of the peasant economy. All these different channels or 'funds' tied the peasants to the Batur Temple which also functioned as an important redistributional center, including the allocation of titles and the confirmation of social reputation (Hauser-Schäublin 2005). These obligations - not to mention earlier obligations they had towards noble leaders or kings - consumed a large portion of peasants' production.

A historical analysis of the Batur Temple is crucial for understanding this institution. Although political and economic conditions have changed, the temple still today plays a significant role in the life of the local community, displaying features that date back to pre-colonial times. In spite of the fact that many of the pre-colonial conditions have changed considerably (democracy instead of monarchy, mass literacy and new crops less dependent on the ritual calendar) the temple's major office holders still perform in many ways as before. However, there is a major difference. There is no longer a royal court with whom the temple and its priests are closely interrelated. The temple has clearly gained autonomy since the formal abolition of kings and kingship. The same applies to the villages and their control over land. However, for one of the most important ritual tasks to be carried out in the Batur temple, the political figure in charge of the worldly power over Bali 
is still essential. Today it is the governor who is the only to perform a fertility ritual which shall ensure the prosperity of the "world", that is, of the plants, animals and people for another year (Hauser-Schäublin 2011). Thus, on this last day, the coalescence of what from today's perspective could be conceived as the distinct domains of economy (or politics) and religion becomes apparent in the tasks the governor (or formerly the king), and in a similar way, the Jero Petinggi, accomplish. These recent observations may help to understand the delicate former relationship between the Batur temple as an institution with landed property, the temple authorities and their ritual administration of water, the king, his representative(s) in Batur, the people - and of course the gods. They all were parts of what we can call property relations (Benda-Beckmann et al. 2006) which are woven into a fine-spun net of rights, obligations and rewards, all bundled by the Batur temple.

Open Access This article is distributed under the terms of the Creative Commons Attribution Noncommercial License which permits any noncommercial use, distribution, and reproduction in any medium, provided the original author(s) and source are credited.

\section{References}

Appadurai, A. (1981). Worship and conflict under colonial rule. A south Indian case. Cambridge University Press, Cambridge.

Benda-Beckmann, F., Benda-Beckmann, K., and M.G. Wiber (eds.) (2006). Changing properties of property. Berghahn, New York.

Bundschu, I. (1985). Probleme der agraren Grundbesitzverfasung auf Bali. Mitteilungen des Instituts für Asienkunde, no. 143. Institut für Asienkunde, Hamburg.

Budiastra, P. (1975). Rajapurana Pura Ulun Danu Batur, Kintamani, Bangli, vol. 1. Museum Bali, Denpasar.

Budiastra, P. (1979). Rajapurana Pura Ulun Danu Batur, Kintamani, Bangli, vol. 2. Museum Bali, Denpasar.

Dirks, N. B. (1987). The hollow crown: Ethnohistory of an Indian kingdom. Cambridge University Press, Cambridge.

van Eck, R. (1878-1880). Schetsen van het eiland Bali. In Tijdschrift voor Nederlandsch Indie, 7. G. Kolff \& Co, Batavia.

Evers, H.-D. (1972). Monks, priests and peasants. A study of Buddhism and social structure in central Ceylon. E.J. Brill, Leiden.

Geertz, C. (1959). Form and variation in Balinese village structure. American Anthropologist 61: 991-1012.

Geertz, H. (1963). Traditional wet-rice peasants: Bali. In McVey, R. (ed.), Indonesia. New Haven.

Goris, R. [1974] (1986). Sekte-sekte di Bali. Bhratara Karya Aksara, Jakarta.

Hägerdahl, H. (2001). Hindu rulers, Muslim subject: Lombok and Bali in the seventeenth and eighteenth centuries. White Lotus Bangkok.

Hauser-Schäublin, B. (2003). The precolonial Balinese state reconsidered. Current Anthropology 44(2): 153-181.
Hauser-Schäublin, B. (2004). Austronesian aboriginality or the ritual organization of the state? A controversy on the political dimension of temple networks in early Bali. History and Anthropology 15(4): 317-344.

Hauser-Schäublin, B. (2005). Temple and king: resource management, rituals and redistribution in early Bali. Journal of the Royal Anthropological Institute. (N.S.) 11: 747-771.

Hauser-Schäublin, B. (2008a). Julah and Sembiran - Sketches of History. In Hauser-Schäublin, B., and Wayan Ardika I. (eds.). Burials, texts and rituals. Ethnoarchaeological investigations in North Bali. Göttinger Beiträge zur Ethnologie, vol. 1. Universitätsverlag Göttingen, Göttingen.

Hauser-Schäublin, B. (2008b). Ritual, Pilgrimage and the Reconfiguration of the State. Sacred Journeys in the Political Landscape of Bali (Indonesia). In Gengnagel, J., Horstmann, M., and Gerald, S. (eds.), Prozessionen, Wallfahrten, Aufmärsche. Bewegung zwischen Religion und Politik in Europa und Asien seit dem Mittelalter. Böhlau, Wien.

Hauser-Schäublin, B. (2011). Spiritualized politics and the trademark of culture. Political actors and their use of adat and agama in post-Suharto Bali. In Madinier, R., and Picards, M. (eds.), The politics of religion in Indonesia: Syncretism, orthodoxy, and religious contention in Java and Bali. Routledge, London.

Hauser-Schäublin, Brigitta and I Wayan Ardika (eds.) (2008). Burials, texts and rituals. Ethnoarchaeological investigations in North Bali. Göttinger Beiträge zur Ethnologie vol. 1. Universitätsverlag Göttingen, Göttingen. http://webdoc.sub.gwdg.de/univerlag/ 2008/GBE1_bali.pdf.

Jha, N. (2002). The bifurcate subak: The social organisation of a Balinese irrigation community. Unpublished $\mathrm{PhD}$ dissertation. Brandeis University: Department of Anthropology.

Lansing, S. J. (1991). Priests and programmers: Technologies of power in the engineered landscape of Bali. Princeton University Press, Princeton.

Lansing, J. S. (2006). Perfect order. Recognizing complexity in Bali. Princeton University Press, Princeton and Oxford.

Liefrinck, F. A. [1920] (1924). Grondenrecht in Boeleleng. In Adatrechtbundels XXIII. Java en Bali. Martinus Nijhoff, 's-Gravenhage, pp. 381-384.

Liefrinck, F. A. (1921). Nog eenige verordeningen en overeenkomsten van balische vorsten. Martinus Nijhoff, The Hague.

Ottino, A. (2000). The Universe within. A Balinese village through its ritual practices. Èditions Kathala, Paris.

Pedersen, L. (2006). Ritual and world change in a Balinese princedom. Carolina Academic Press, Durham.

Petersen, L. (2006). On irrigation and the Balinese state. Comment. Current Anthropology 46: 306.

Reuter, T. (2002). Custodians of the sacred mountains. Culture and society in the Highlands of Bali. University of Hawai'i Press, Honolulu.

Rudner, D. (1994). Caste and capitalism in colonial India. The Nattukottai Chettiars. University of California Press, Berkeley.

Schoenfelder, J. W. (2003). Negotiating poise in a multihierarchical world: An archaeological exploration of irrigated rice agriculture, ideology, and political balances in the coevolution of intersecting complex networks in Bali. Unpublished $\mathrm{PhD}$ dissertation. University of California, Los Angeles.

Schulte Nordholt, H. (1996). The spell of power. A history of Balinese politics, 1650-1940. KITLV Press, Leiden.

Stein, B. (1980). Peasant state and society in Medieval South India. Oxford University Press, Delhi.

Stein, B. (1989). Vijayanagara. India I. 2. Cambridge University Press. Stuart-Fox, D. (2002). Pura Besakih. Temple, religion and society in Bali. KITLV Press, Leiden. 
Strauß, Sophie (2006) Konkurrenz um die Ressource Wasser. Nutzungskonflikte am Beispiel der südbalinesischen Reiskultur. Göttingen: Magisterarbeit der Sozialwissenschaftlichen Fakultät. http://resolver.sub.uni-goettingen.de/purl/?webdoc-1753.

Wälti, Samuel (1997). Kintamani. Dorf, Land und Rituale. Entwicklung und institutioneller Wandel in einer Bergregion auf
Bali. Culture, Society, Environment- South Asian and south East Asian Studies. Münster, LIT.

Wiener, M. J. (1995). Visible and Invisible Realms: Power, Magic, and Colonial Conquest in Bali. University of Chicago Press, Chicago.

Wolf, E. (1966). Peasants. Foundations of Modern Anthropology Series. Prentice Hall, Englewood Cliffs. 